\title{
Improvement Of Writing Batik Skills of PKK Women, Tajinan Village, Kepanjen District, Malang Regency
}

\author{
Ratnawati ${ }^{1 *}$, Kustyarini $^{2}$ \\ ${ }^{1)}$ Faculty of Economics and Business, University of Wisnuwardhana Malang \\ ${ }^{2)}$ Faculty of Teacher Training and Education, Wisnuwardhana University Malang \\ E-mail: ratnawati_unidha@yahoo.com
}

\begin{abstract}
The purpose of this service at PKK RW.06 Tajinan village, Kepanjen sub-district, Malang Regency is to empower PKK members with various activities that can improve their economy. Activities carried out by making batik from the initial process until it becomes batik cloth and processing it into skills that have economic value. The method used is by transferring knowledge to members of PKK RW.06 Tajinan village, Kepanjen sub-district, Malang Regency, covering the process of batik until it becomes a skill that is ready to be sold. and food packaging with direct assistance. Results devotion to community train skills member of PKK RW.06 Tajinan village, Kepanjen sub-district, Malang Regency in the resulting batik PKK members. Keywords: Batik Skills, PKK, Economic Improvement
\end{abstract}

\section{INTRODUCTION}

Tajinan Village is one of the villages located in Tajinan District, Malang Regencywith a strategic location close to public facilities and facilities, such as: Puskesmas and Tajinan Market. Tajinan village has an average population of entrepreneurs, market traders, teachers so that it has various demographic characteristics. Housewives and teenagers from Tajinan village have a weekly and monthly gathering schedule (gymnastics and social gathering) without any innovative and creative activities. PKK RW 06 women have gathering activities only for arisan and PKK activities without any programs creative activities.

The need for more creative and qualified skills is urgently needed by the PKK group of RW.06 Tajinan village, Kepanjen sub-district, Malang Regency as an effort to increase their household income. The need to increase skill potentials is a challenge in the world of work. Lack of attention to housewives for their creativity, in order to develop and become housewives who, independently encourage writers to be able to solve these problems. The existence of the concept of batik training (SINAU MBATIK) is one of the efforts to improve the skills of women and youth in Tajinan Village to increase their household income. This batik training process requires assistance for the success of the SINAU MBATIK program with stages from how to make patterns, sticking, coloring and sag of the night (candles). The SINAU MBATIK program is carried out with the hope of stimulating women to be skilled and innovative during group activities in RW 06 Tajinan Village, Tajinan District, Malang Regency. Mastery of certain skills becomes the main capital in developing the economic potential of everyone.

According to Simamora (2014) training is a series of activities designed to improve skills, experience knowledge or change one's attitude. Meanwhile, Sastrodipoera (2006) in Kamil (2010) provides a definition of training as "a type of learning process to acquire and improve skills outside the human resource development system, which applies in a relatively short time with methods that prioritize tactics rather than theory. 
Training is oriented to the present and helps employees to master specific skills and abilities (competencies) to succeed in their jobs (Dessler, 2015). The number of women in Tajinan Village which reaches more than a quarter of the population is a local potential that can be developed from an economic perspective, one of which is entrepreneurship. Community Service Activities (PKM) in this case seek an activity that has positive economic value, namely How to improve batik skills as a 'business opportunity' through training and mentoring of batik skills. This activity will not only fill their meeting schedule, but will also strengthen individual empowerment, through sharpening their batik skills.

The problems that will be solved through this activity basically cannot be separated from the scope of the problems above, namely: (1) How to fill in positive and innovative activities for housewives when they gather, so that they can increase the creativity of housewives using the Sinau Mbatik method? (2) How to increase economic income and grow the entrepreneurial spirit of housewives and teenagers in Tajinan village?

From this background, the program objectives can be formulated, namely: (1) Filling in positive and innovative activities for housewives when they gather, so as to increase the creativity of housewives (2) Providing batik skills for housewives and teenagers to become a selling value product to increase household economic income (3) Providing assistance with batik tools (4) Increasing economic income and fostering the entrepreneurial spirit of housewives and teenagers in Tajinan village.

\section{METHOD}

The implementation method in the process of batik skills training activities in RW 06 Tajinan Village, Tajinan District, Malang Regency is as follows:(1) discussion with PKK mothers regarding their needs and expectations in written batik skills (2) from this discussion, the training needed and the making of the module was determined, (3) carried out batik training starting from making patterns (batik pictures), canting to the coloring process, sag candles (4) evaluation and mentoring in training. The following is a table of batik training activities:

Table 1. Batik Training Activities

\begin{tabular}{|l|l|}
\hline Training materials & \multicolumn{1}{c|}{ Sub subject } \\
\hline Basics of batik & $\begin{array}{l}\text { Introducing batik tools } \\
\text { Sketch }\end{array}$ \\
\hline Batik Process I & $\begin{array}{l}\text { Drawing sketch on cloth } \\
\text { The process of attaching }\end{array}$ \\
\hline Batik process II & $\begin{array}{l}\text { Coloring process } \\
\text { Finishing }\end{array}$ \\
\hline Produce skill products & $\begin{array}{l}\text { Training on making pillowcases, tissue } \\
\text { holders, tablecloths, bags and wall } \\
\text { hangings. }\end{array}$ \\
\hline
\end{tabular}

The first step in batik skills training is by providing the main points of material to PKK RW women. 06 Tajinan village, Malang Regencyinclude:

1. Teaches how to make batik patterns

2. Drawing batik patterns onto fabric

3. Tag

4. The process of coloring batik motifs 
5. Batik block coloring process

6. Become a finished product in accordance with the wishes of mothers and teenagers.

Mentoring and guidance for mothers is carried out once a week on Sunday, because students have no activities on campus as well as mothers and teenagers who have free time on Sundays. So we can easily communicate this program support from youth organizations and local residents. The batik training program is carried out by the team, as a result of participating in the Community Service program.

\section{Implementation Results}

\section{RESULTS AND DISCUSSION}

The implementation of the Community Service program includes training in basic batik techniques from drawing patterns, canting, coloring, lorot (removing wax). After the basic cloth becomes batik cloth, training on skills to make goods that can be sold, so as to increase economic value is carried out including (making batik paintings (wall decorations), pillowcases, tablecloths, tissue holders, bed covers (blankets)). The training started from May to July 2018 which took place at Balai RW 6 Tajinan Village, Kepanjen District, Malang Regency, by holding training for 3 times starting from 11.00 WIB to 14.00 WIB
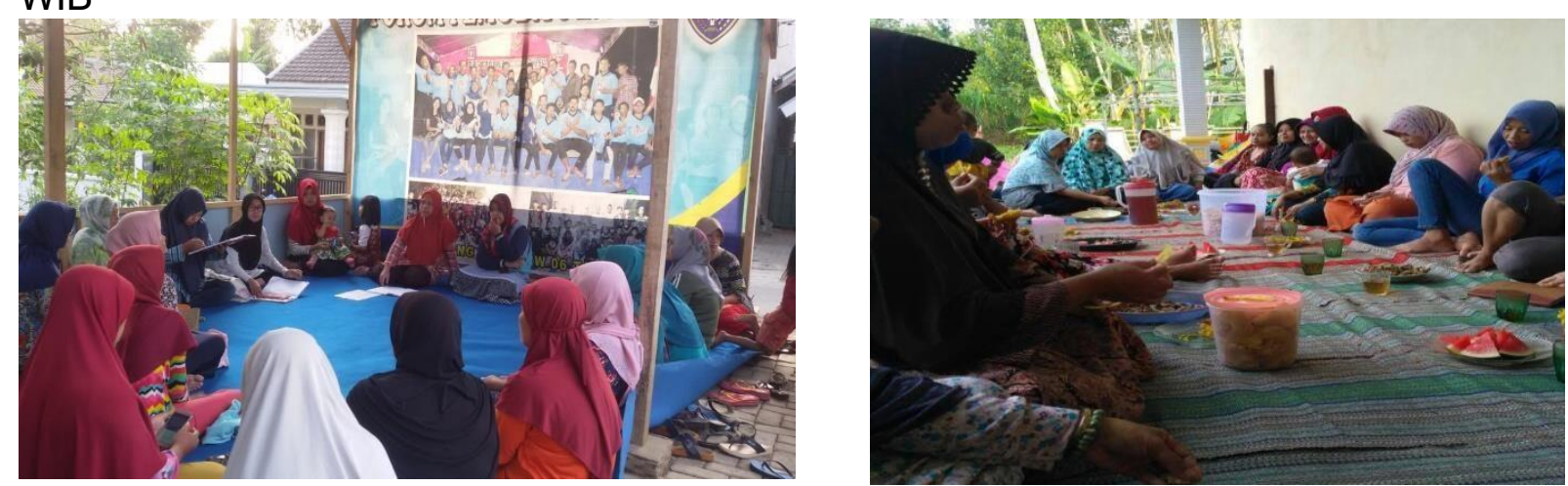

Figure 1. Documentation of mothers gathered in PKK RW batik writing skills training. 06 Tajinan Village, Kepanjen District, Malang Regency.

Furthermore, the number of participants who attended the training activities were PKK RW Members. 06 Tajinan Village, Kepanjen District, Malang Regency, where initially only 25 people attended the activity, but enthusiastically members of the RW PKK. 06 increased to 40 people. The initial meeting of the batik skills training activity was only $20 \%$ of the PKK RW members. 06 Tajinan Village, Kepanjen District, Malang Regency, who have batik skills, because they have participated in batik training activities from the local government. The Community Service Team began to foster PKK RW members. 06 Tajinan Village, Kepanjen District, Malang Regency with basic techniques from beginning to finishing to produce batik cloth. This was done for 3 times of training (basic batik, process of batik I and process of batik II). From the results of these training activities, all members of the PKK RW. 06 Tajinan Village, Kepanjen District, Malang Regency is able to make cloth with batik motifs (typical of Bululawang). The next training, the PPDM team processed the batik cloth with PKK RW members. 06 Tajinan Village, Kepanjen District, Malang Regency, are ready to sell handicrafts (wall decorations, bags, tissue holders, tablecloths, pillowcases and so on). The process of making these skills is carried out in 3 
meetings from 10 people who can make patterns and sew into 25 who are able to make patterns and sew themselves. 06 Tajinan Village, Kepanjen District, Malang Regency, are ready to sell handicrafts (wall decorations, bags, tissue holders, tablecloths, pillowcases and so on). The process of making these skills is carried out in 3 meetings from 10 people who can make patterns and sew into 25 who are able to make patterns and sew themselves. 06 Tajinan Village, Kepanjen District, Malang Regency, are ready to sell handicrafts (wall decorations, bags, tissue holders, tablecloths, pillowcases and so on). The process of making these skills is carried out in 3 meetings from 10 people who can make patterns and sew into 25 who are able to make patterns and sew themselves. Here are some documentations of Community Service activities in the batik training process:

Activity Giving Adhesive/Binder color.

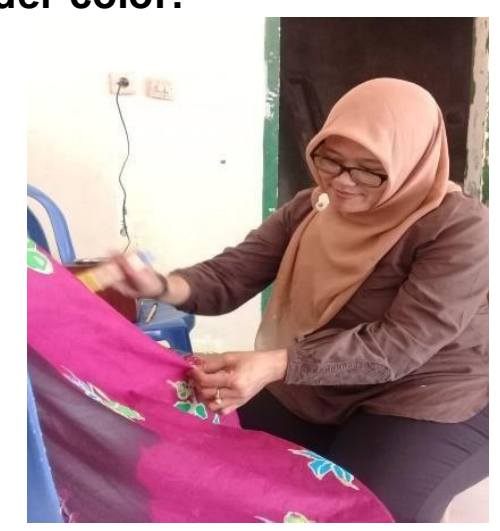

Figure 2. Mencanting activities for PKK RW women. 06 Tajinan Village, Kepanjen District, Malang Regency
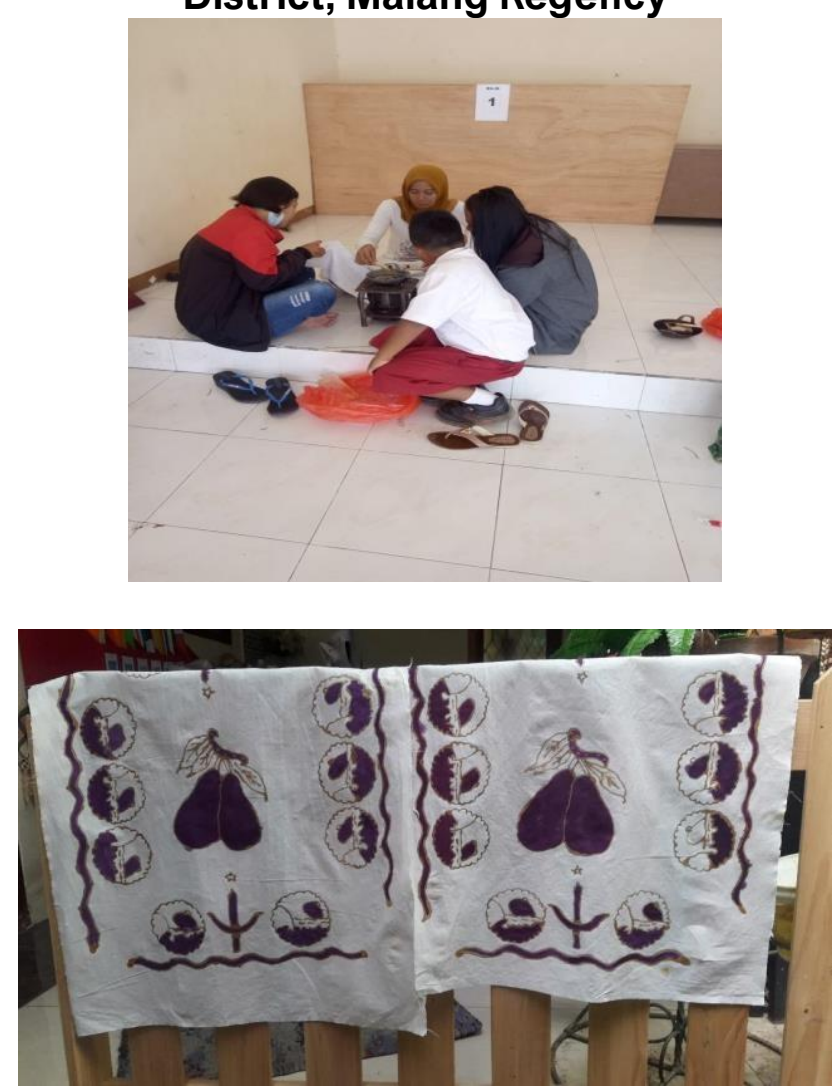

Figure 3. Brush Coloring Process: 


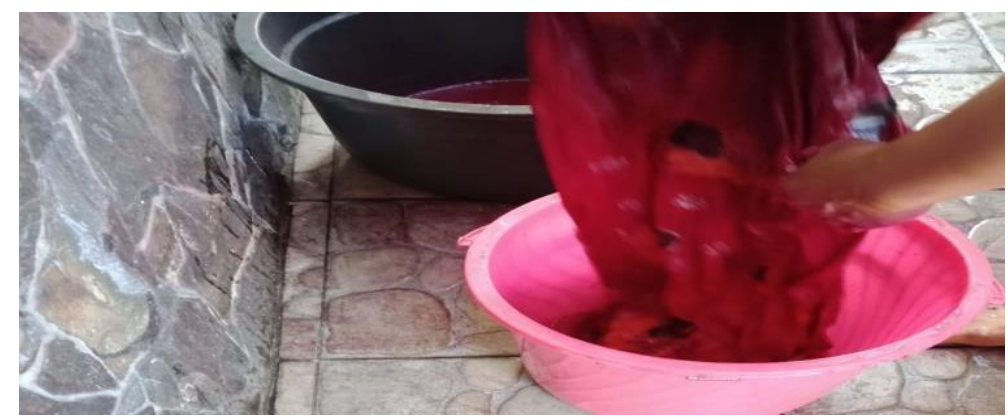

Figure 4. Dyeing process by dyeing

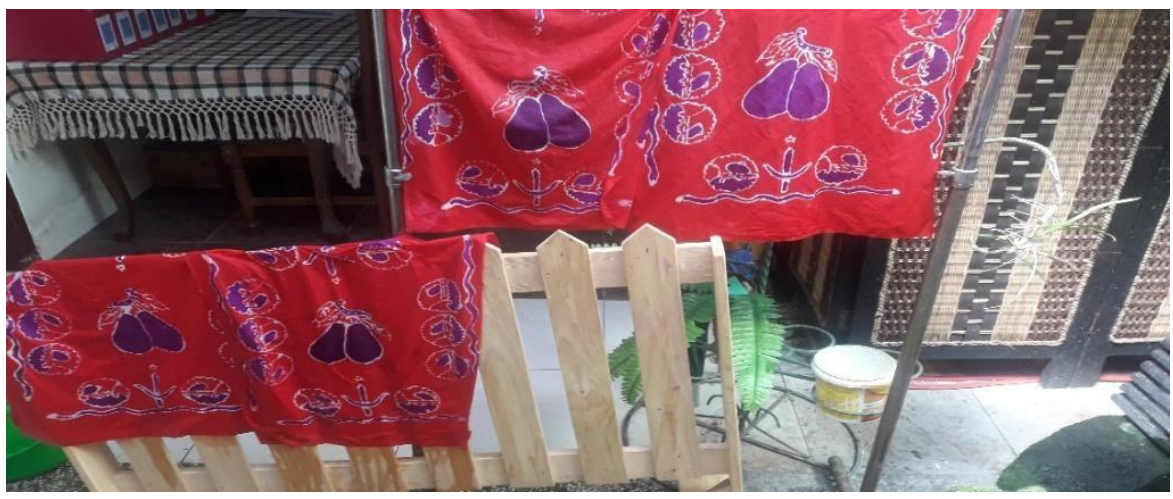

Figure 5. Drying Process

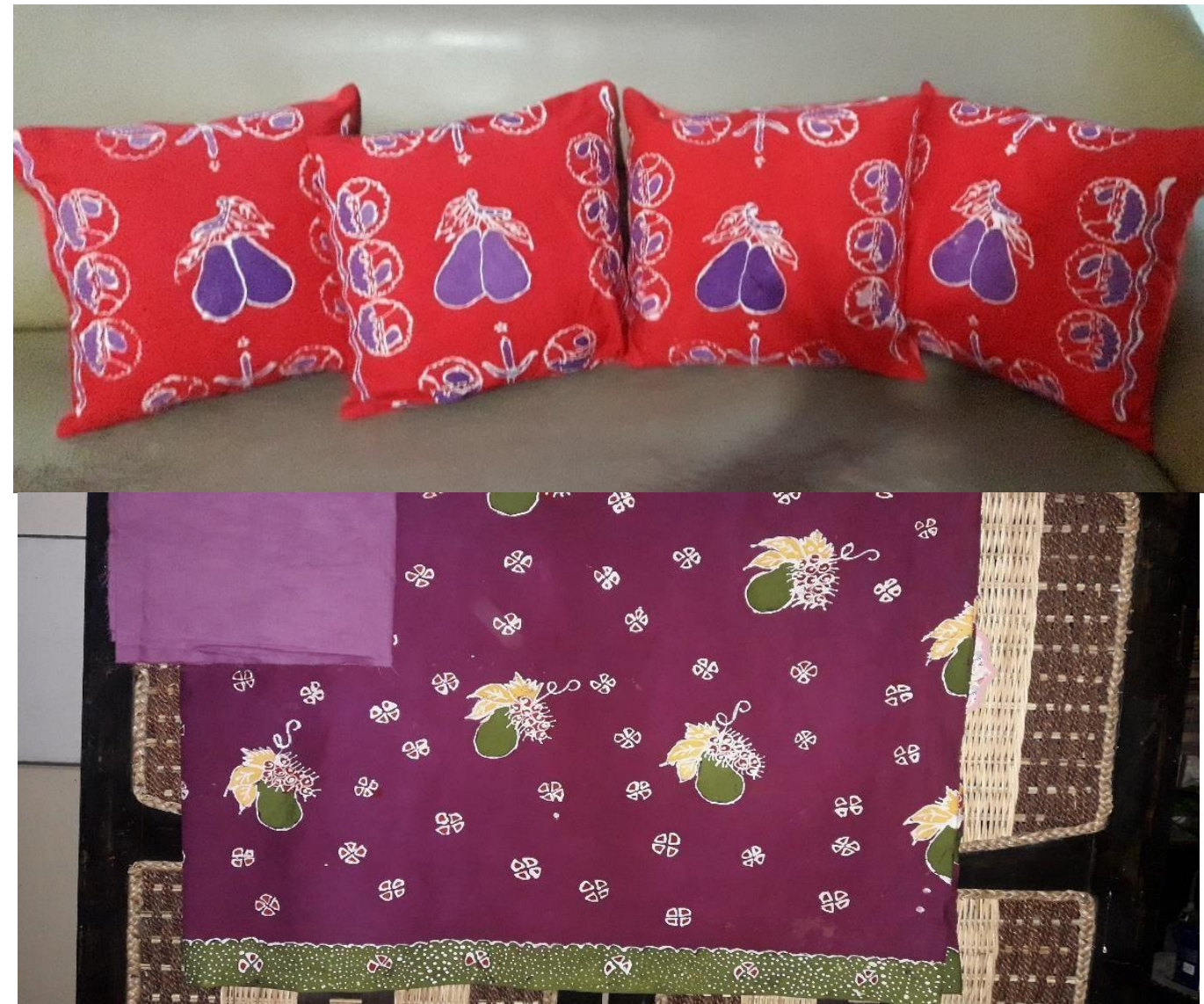

Figure 6. The result of being one of the batik products 


\section{DISCUSSION}

Some of the results of training products from PKK RW members. 06 Tajinan Village, Kepanjen District, Malang Regency, will then be used as one of the products included in the exhibition organized by Kepanjen District, Malang Regency regarding the exhibition of SME products. Participation in the exhibition will introduce the products of the fostered partners to the relevant agencies/agencies and the wider community.

In addition to the training methods carried out to partners, the team also provides regular assistance. This assistance is intended so that partners experience good progress in terms of knowledge, product creation, and motivation. Mentoring is carried out at least once a week. In mentoring, the team tries to accommodate difficulties and tries to find solutions.

\section{CONCLUSION}

The presence of this Community Service program greatly contributed to improving the skills of PKK RW women. 06PKK RW. 06 Tajinan Village, Kepanjen District, Malang Regency. From the community service activities that have been carried out, the following conclusions can be drawn: Service participants have gained knowledge and skills about making more diverse batik motifs. Service participants have gained knowledge and skills in the process of tracing sketches, canting, coloring to waxing (finishing). Service participants can also develop the product packaging they produce (a variety of chips) and do marketing through Facebook and Instagram.

The knowledge and skills acquired by the service participants are expected to be transmitted to PKK mothers in other villages in Malang Regency. The addition of various models and developing with the types of batik products produced, thus adding to the collection in the marketing of batik products. There needs to be cooperation and monitoring from the relevant agencies for the continuity of activities.

\section{REFERENCES}

Dessler, Gary. (2015). Human Resource Management. Jakarta: Four Salemba. Kamil (2010). Education and Training Model (Concept and Application). Bandung: Alphabet.

Simamora, Henry.(2014). Human Resource Management. Yogyakarta: YKPN High School Publishing Section.

Sastradipoera, Komaruddin. (2005). Human Resource Management, An Operative Function Approach. Bandung : Kappa Sigma 